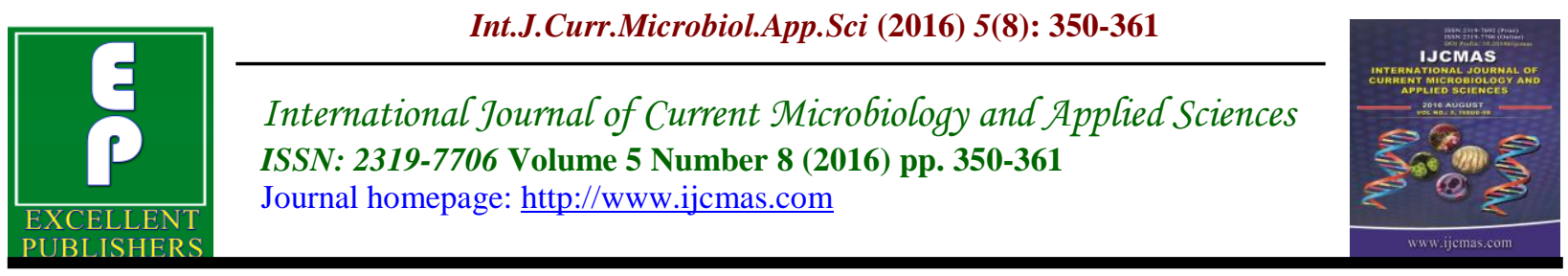

Original Research Article

http://dx.doi.org/10.20546/ijcmas.2016.508.037

\title{
Genotyping Study of Hydatid Cyst by Sequences of ITS1 - rDNA in Thi-Qar - Southern of Iraq
}

\author{
Wesam Jasim Hansh ${ }^{1 *}$ and Abdul-Hussien Habash Awad ${ }^{2}$ \\ ${ }^{1}$ Thi-Qar Directorate of Education, Iraq \\ ${ }^{2}$ College of Education for Pure Sciences, University of Basrah, Iraq \\ *Corresponding author
}

Keywords

Hydatid cyst, genotyping, PCR - RFLP, Sequence of ITS1, Thi-Qar province.

\begin{tabular}{l}
\hline Article Info \\
\hline Accepted: \\
17 July 2016 \\
Available Online: \\
10 August 2016
\end{tabular}

\section{A B S T R A C T}

The present study aims to identify strains of E.granulosus which infect human and intermediate hosts (sheep, cattle, buffaloes and camels) in Thi-Qar province by using PCR - RFLP technique. The molecular study is carried out on 75 hydatid cyst: include 25 human cyst were collected from Al-Hussein Imam Teaching Hospital. The samples of intermediate hosts hydatid cyst were collected from the abattoir of Nassiriyah municipality which included 25 cyst of sheep, 20 cyst of cattle, 3 cyst of buffaloes and 2 cyst of camels. The DNA is extracted from protoscolices of hydatid cysts isolated from infected organs. The PCR technique was used for amplification of rDNA - ITS1 gene. The PCR products isolated from different organs of human and others intermediate hosts were $1000 \mathrm{bp}$ which is similar for sheep strain genotype 1. The results of PCR - RFLP analysis using Alu1 restriction enzyme with PCR product of ITS1 gene show two bands $800 \mathrm{bp}$ and 200 bp while the size of bands by using Rsal restriction enzyme was 655 bp and 345 bp. Depending on PCR - RFLP patterns in all studied samples, it can be concluded that sheep strain G1 of E.granulosus is predominant in Thi-Qar province. Sequence analysis for ITS1 gene demonstrate the presence of sheep strain genotype 1 depending on sequences data for ITS1 gene in all samples which were similar 100 $\%$ for sheep strain in gene bank except one sample isolated from liver of an infected sheep which differs in position of nucleotide sequence and similar $99 \%$ for sequence of sheep strain. The data base of this new strain is recorded in gene bank for DNA sequence in NCBI and ENA for the first time under the name Echinococcus granulosus strain WH1AW2 (GenBank: LT547814.1).

\section{Introduction}

Cystic echinococcosis, CE (also called Hydatidosis) is a widespread zoonosis infecting a large number of wild and domestic animals and humans (Bouree, 2001). It is an important economic and zoonotic disease, caused by metacestode of adult worms of the genus Echinococcus
(McManus \& Smyth, 1986). Hydatidosis in Iraq is caused by Echinococcus granulosus which is hyper endemic (Molan,1993). E. granulosus has a number of genetically distinct strains, which are known to differ phenotypically. To date, ten genotypes (G1 - G10) of E. granulosus have been identified using molecular tools (McManus 
and Thompson, 2003; Nakao et al., 2007). The 10 distinct genotypes (G1-G10) have been described in world based on nucleotide sequence analysis of the mitochondrial cytochrome Oxidase subunit 1 (CO1), dehydrogenase subunit 1 (NDI) gene and intra transcribed spacer 1 ( ITS1). These different genotypes have been associated with distinct, intermediate hosts: sheep, pigs, cattle, horses, camels, goats and cervids (Sanches et al., 2010). Recently it has been proposed that E. granulosus may be a species complex which are likely to be maintained in distinct cycles of transmission comprising of E. granulosus sensus stricto (genotypes G1-G3), E. equinus (genotype G4), E. ortleppi (genotype G5), G6/G7, E. canadensis (genotypes G8 and G10) and E. felidis (lion strain) (Nakao et al., 2007; Huttner et al., 2008).

PCR-based methods have been extensively used to characterize the different strains of E. granulosus (Adwan et al., 2013). Molecular techniques allow a direct characterization of the genome of the parasite and have an advantage that they are not confounded by variability induced by the host or the environment (Bowles and McManus, 1993b). Various techniques such as polymerase chain reaction based on restriction fragment length polymorphism (PCR-RFLP) were used to determine variation within E. granulosus (Parija, 2004). The present study aims to determine genetic variability for E.granulosus which becomes one of the most important principles and challenges that face the researchers in putting strategies to control on the disease.

\section{Materials and Methods}

\section{Samples collection of hydatid cysts}

Samples of human hydatid cysts were collected immediately from patients via surgery after coordination with a surgeon in operations ward of Al-Hussein Imam Teaching Hospital in Thi-Qar province, and these samples include hydatid cysts isolated from liver, lung and kidney of human, while samples of animals Hydatid cysts were collected after their isolation from livers and lungs of slaughtered animals (sheep, cattle, buffaloes and camels) in the abattoir of Nassiriyah municipality in Thi-Qar province southern of Iraq.

\section{Collection and Preservation of Protoscolices}

According to McManus \& Smyth (1978), the hydatid cyst contents (fluid and protoscolices) were aspirated aseptically with some simple modifications then the sediment of protoscolices preserved in freezing until their using in molecular analysis .

\section{Molecular study}

Molecular analysis for protoscolices of E.granulosus hydatid cysts after their isolation from human and some intermediate hosts were carrying out in laboratory of PCR unit in animal house, Department of Biology / College of Education for Pure Science and laboratory of Cell Researches Unit, Department of Biology / College of Science / University of Basrah.

\section{DNA Extraction}

Total E. granulosus genomic DNA was prepared from samples of protoscolices preserved in freezing. The DNA was isolated by using the gSYNC ${ }^{\mathrm{TM}}$ DNA Extraction Kit (Geneaid) according to the manufacturer's protocol for DNA isolation from tissues. Electrophoresis is carrying out to visualize DNA according to Sambrook et al., (1989). The extracted DNA was loaded in TBE agarose gel $1 \%$ stained with 
ethidium bromide solution and electrophoresed at $80 \mathrm{~V}$ for 20 minute. The bands of DNA were visualized in UV transilluminator and the gel was photographed directly by digital camera. The genomic DNA was stored at $-20^{\circ} \mathrm{C}$.

\section{Polymerase Chain Reaction / Restriction Fragment Length Polymorphism PCR Process}

PCR - RFLP technique is used in this study by using Internal transcribed spacer subunit 1 ITS1 gene for 75 hydatid cyst sample that include 25 hydatid cyst from human (15 livers, 9 lungs, and 1 kidney) were collected from Al-Hussein Imam Teaching Hospital in Thi-Qar province. The hydatid cysts which were obtained from intermediate hosts slaughtered in abattoir of Nassiriyah municipality included 25 hydatid cyst for sheep (15 livers and 10 lungs), 20 hydatid cyst (6 livers and 14 lungs) for cattle, 3 hydatid cyst (2 liver and 1 lung) for buffaloes and 2 hydatid cyst (1 liver and 1 lung) for camels.

PCR was performed for amplifying the Internal transcribed spacer subunit 1 (ITS1) for all samples of genomic DNA which prepared from protoscolices .Two primers of BD1 (Forward) with (BD1: 5'GTC GTA ACA AGG TTT CCG TA'3) sequence and 4S (Reverse) with 4S: 5'TCT AGA TGC GTT CGA (A/T) GTC GAT G'3) sequence were used for this purpose. These primers have been designed by Bowles and McManus (1993a).

The PCR reaction was performed in a final $25 \mu \mathrm{l}$ volume by adding mixture of reaction to PCR microtubes which contain $5 \mu$ l master mix from bioneer company, $0.5 \mu 1$ from each primer (Forward and Reverse), 5 $\mu 1$ DNA sample and $14 \mu \mathrm{l}$ from nuclease free water. The reaction was carried out in
Thermocycler under the following conditions: one cycle of $95^{\circ} \mathrm{C}$ for 5 minutes (primary denaturation), followed by 30 cycle of $94^{\circ} \mathrm{C}$ for 30 seconds (denaturation), $55^{\circ} \mathrm{C}$ for 45 seconds (annealing) and $72^{\circ} \mathrm{C}$ for 45 seconds (extension), and one cycle of final extension $72^{\circ} \mathrm{C}$ for 5 minutes. PCR product was loaded on TBE agarose gel $1.5 \%$. The gel stained with $0.1-0.3 \mu \mathrm{l}$ from ethidium bromide stain. Electrophoresis carried out at $70 \mathrm{~V}$ for 90 minutes. The bands were examined for visualization amplified PCR product (ITS1) in UV transilluminator and digitally photographed.

\section{RFLP process}

Two restriction endonuclease (Alul and Rsal) were used in digestion of PCR product for ITS1 gene. The mixture of reaction for Alul (AG/CT) restriction endonuclease performed in a final $20 \mu \mathrm{l}$ volume consist of $1 \mu \mathrm{l}$ restriction endonuclease Alu1, $4 \mu \mathrm{l}$ DNA (PCR product), $2 \mu 1$ 10x green buffer and $13 \mu 1$ nuclease free water. The microtubes were closed and centrifuged for 5 seconds by microcentrifuge. The reaction was carried out in thermocycler under a temperature of $37^{\circ} \mathrm{C}$ for activation of Alul for 1 hour then temperature for inhibition of Alul was $65^{\circ} \mathrm{C}$ for 20 minutes for stop activity of Alul. These procedures were carried out according to the manufacturer's protocol with Alul restriction endonucleases.

The mixture of reaction for $R s a l$ (GT/AC) restriction endonuclease performed in a final $20 \mu \mathrm{l}$ volume consist of $1 \mu \mathrm{l}$ restriction endonuclease Rsal, $4 \mu \mathrm{l}$ DNA (PCR product), $2 \mu \mathrm{l} 10 \mathrm{x}$ green buffer and $13 \mu \mathrm{l}$ nuclease free water. The microtubes were closed and centrifuged for 5 seconds by microcentrifuge. The reaction was carried out in thermocycler under a temperature of $37^{\circ} \mathrm{C}$ for activation of $R S A l$ for 1 hour and 
according to the manufacturer's protocol with Rsal restriction endonucleases.

Electrophoresis performed for examination sizes of restriction products by using Alul and Rsal in TBE 2\% agarose gel stained with ethidium bromide stain. The bands of restriction of products were visualized in UV transilliminator and photographed directly by a digital camera.

\section{ITS1 - rDNA Sequences}

The samples of PCR product of ITS1 gene send to Macrogen company in South Korea for sequencing. The volume of PCR product was $25-30 \mu 1$ and concentration of primers (Forward and Reverse) is $17 \mathrm{picomol} / \mu \mathrm{l}$ for each sample. These samples were identified using the PCR sequencing products of ITS1 gene in "Blast" provided by The National center for Biotechnology Information service (NCBI). $\quad$ http:// www.ncbi.nlm.nih.gov.

\section{Results and Discussion}

\section{Molecular study}

The results of PCR were demonstrated for amplifying ITS1 gene in all samples of DNA which prepared from protoscolices of hydatid cysts by using BD1 (forward) and $4 \mathrm{~S}$ (reverse) primers show the appearance of bands with 1000 base pair in all samples of DNA of protoscolices in human, sheep, cattle, buffaloes and camels in different organs which is similar for sheep strain genotype 1 as in Figure (1) and (2).

The restriction results for ITS1 gene by Alul(5'AG/CT'3) show the appearance of two bands with 800 bp and 200 bp Figure (3 A , B), while the results of restriction by Rsal (5'GT/AC'3) show the appearance of two bands 655 bp and 345 bp Figure (4 A ,
B). The sizes of restriction for ITS1 gene by Alul and Rsal enzymes demonstrate the same bands in all samples of study which are similar to sheep strain genotype 1 .

\section{Sequence analysis for rDNA - ITS1 gene}

The analysis of nucleotide sequence for 10 samples of DNA (ITS1) gene send to macrogen company in Korea. These samples include three samples of hydatid cyst of liver and lung sheep and three samples of liver, kidney and lung of human, and two samples of liver and lung of cattle and one sample of buffalo's liver and camel's lung.

The results of sequence analysis for ITS1 gene show the presence of sheep strain genotype 1 depending on sequence data of ITS1 gene in all samples which was similar $100 \%$ for sheep strain in GenBank except one sample of hydatid cyst isolated from sheep liver's which differ from reference strain in position of nucleotide sequence and this sample is similar with $99 \%$ for sequence of reference strain. All samples were published by European Nucleotide Archive (ENA) and National Center for Biotechnology Information (NCBI) which is a part of United State National library of Medicine. The data base of this new strain was record in the GenBank for DNA sequences for the first time under the name Echinococcus granulosus strain WH1AW2 (GenBank: LT547814.1) which is similar with $99 \%$ to reference strain. The sequence analysis of this strain demonstrates the presence of point mutation type transition Guanine (G) instead of Adenine (A) at position 370. Figure (5).

The results of the present study by using PCR - RFLP shows that the genotype or strain of E.granulosus in all DNA samples prepared from protoscolices of human, sheep, cattle, buffaloes and camels belong to 
sheep strain (genotype 1) of E.granulosus in Thi-Qar province. The bands of amplifying rDNA - ITS1 gene demonstrate molecular weight 1000 base pair which are similar for sheep strain. This result was agree with studies of Bowles \& McManus (1993a) and Parsa et al., (2011) and Hanifian et al., (2013) which show the size of bands for product of ITS1 gene amplification as 1000 base pair in sheep strain of E.granulosus. RFLP patterns produced from restriction enzymes Alul and Rsal on all PCR products of ITS1 gene show the presence of sheep strain in Thi-Qar province, and according to this study the sheep strain is a major source for hydatidosis in human, sheep, cattle, buffaloes and camels and this findings confirmed on the importance of sheep as a source of infecting the $\operatorname{dogs}$ and, subsequently the human.

The results of the present study disagreed with the results of Aljawady (2009) in Mousil province which is demonstrate two strains dog / sheep strain and dog / cattle strain depending on morphological characters, also disagreed with a study of AL-Krawy (2004) in Sallahuddin province showing different isolates which classified as separated strains of E.granulosus, and showed similarities between protosclioces from sheep and goat while differ from protoscolices of cattle, he recorded dog / goat strain. The results of present study disagree with molecular study of Khalf et al.(2014) in Baghdad province (depending on PCR technique for amplifying ITS1 gene) whom demonstrated that most of patients with hydatidosis is related to horse strain G4, sheep strain G1, buffaloes strain G3, Cattle strain G5, Camels strain G6 and pig strain G7 of E.granulosus, these genetic patterns are predominant which is infect human in Iraq. The difference of present molecular study from these studies may be due to the morphological characters which affected by environmental factors and host.
The morphological characters may be affected by the disappearance of rostellar hooks of protoscolices and of adult worms and, subsequently gave inaccurate results. Hobbs et al.(1990) show much disagreement of using morphological criteria on their own for strain characterization and there is now irrefutable evidence that some morphological characters of the Echinococcus organisms are significantly affected by the host. The molecular techniques by using PCR - RFLP allow a direct characterization of parasite genome for amplification of rDNA - ITS1, then effect the restriction enzymes on limited sequence in this gene, therefore genetic characters are not necessary directly reflected in physiological or morphological differences.

The results of this study is similar to results done by Parsa et al., (2011) and Hanifian et al., (2013) in Iran which showed that every sheep, cattle and goat is infected by sheep strain of E.granulosus. Vahedi et al., (2014) in Iran show that all samples of hydatid cysts collected from different organs in human is similar to sheep strain by using PCR - RFLP for rDNA - ITS1gene, also Vural et al., (2008) and Utuk et al., (2008) in Turkey show the predominant genotype of sheep strain. El-Madawy et al., (2011) in Egypt demonstrates that sheep and cattle are infected by sheep strain by using PCR RFLP. Shahzad et al., (2014) showed sheep strain in cattle, buffaloes, sheep and goats in Pakistan, and Bhattacharya et al., (2008) in India and Bowles \& McManus (1993a) which recorded sheep strain. The present study agreed with many of other molecular studies in many of countries which demonstrate that the cattle are infected by sheep strain (Thompson \& Lymbery, 1995; WHO, 2002; Romig et al., 2006), but disagreed with studies by Harandi et al., (2002) and Ahmadi \& Dalimi (2006) in Iran which record camel strain G6 in samples 
from human. Camels and cattle represent different genotype from genotype of sheep strain while sheep strain is a common predominant. In Turkey Snabel et al., (2009) recorded pig strain G7 in samples of human and hydatid cysts in sheep classified as genotypes G1, G3, and G7. Khalifa et al., 2014) in Egypt demonstrated that all samples of hydatid cysts which isolated from camels and human are similar to camel strain G6. Rinaldi et al., (2008) in southern of Italy find strain G1, G2 and G3 in cattle and buffaloes.

The present study shows that buffaloes and cattle are infected by sheep strain and the life cycle for E.granulosus is the dog / sheep cycle which represents predominant cycle and responsible for human and other intermediate hosts infection and subsequently, the genotype G1 is predominant in transmission of E.granulosus, therefore the existence of other strain responsible of human and other intermediate hosts infection explain another transmission cycles for strains of E.granulosus in this study. In Iran two distinct cycle which are dog / sheep cycle and dog / camels cycle were found which interfere and reacts with each other and subsequently the infections causes by strains of sheep and camels which are assessed in camels and sheep respectively as well as human infection (Jamali et al., 2004 ; Thompson et al., 2006; Karimi \& Dianatpour, 2008).

Fig.1 Agarose gel electrophoresis of ITS1 gene. L: Ladder (1500bp). (1) and (2) sheep liver, (3) and (4) liver and kidney of human, (5) cattle liver, (6) buffaloes liver and (7) Camel liver.

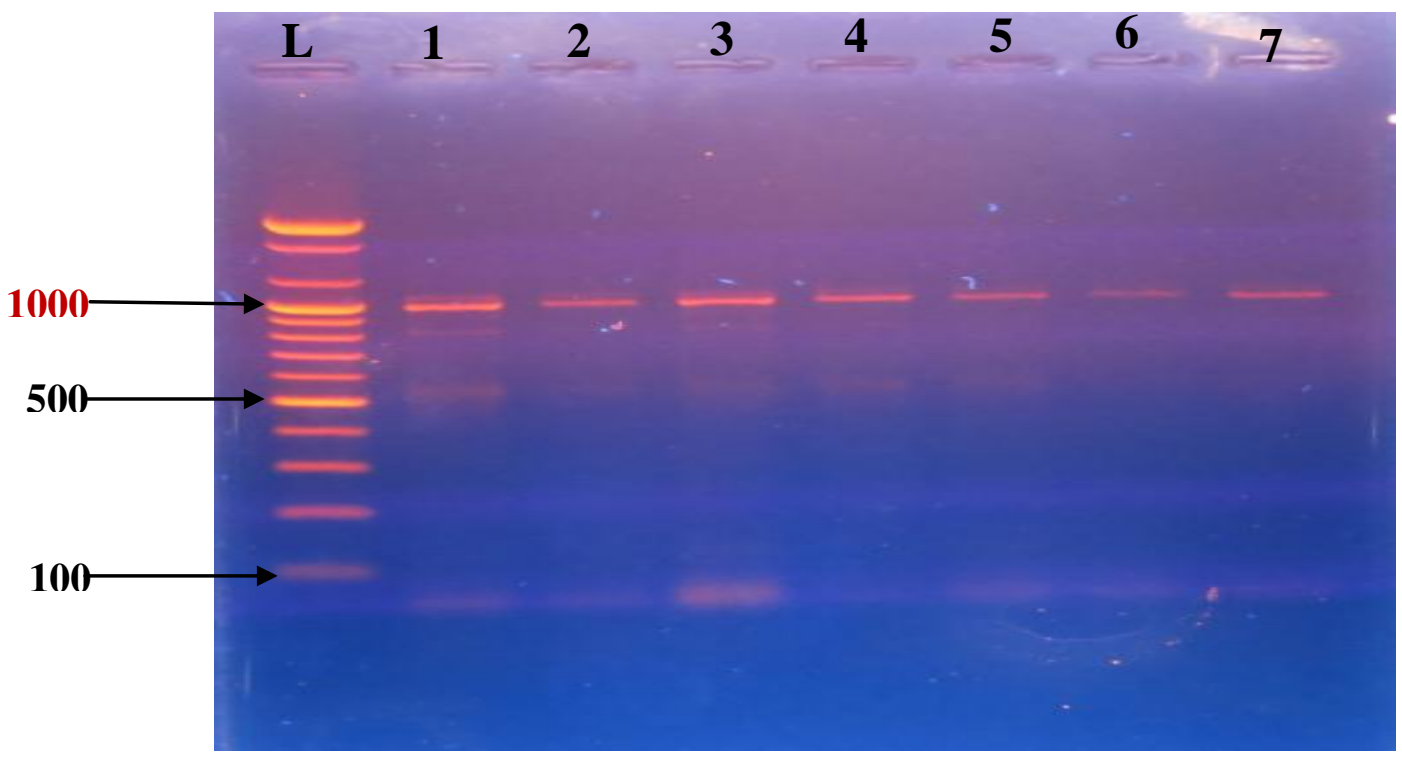


Fig.2 Agarose gel electrophoresis of ITS1 gene. L: Ladder (1500bp). (1) and (2) sheep lung, (3) and (4) human lung, (5) cattle lung, (6) buffaloe lung and (7) Camel lung.

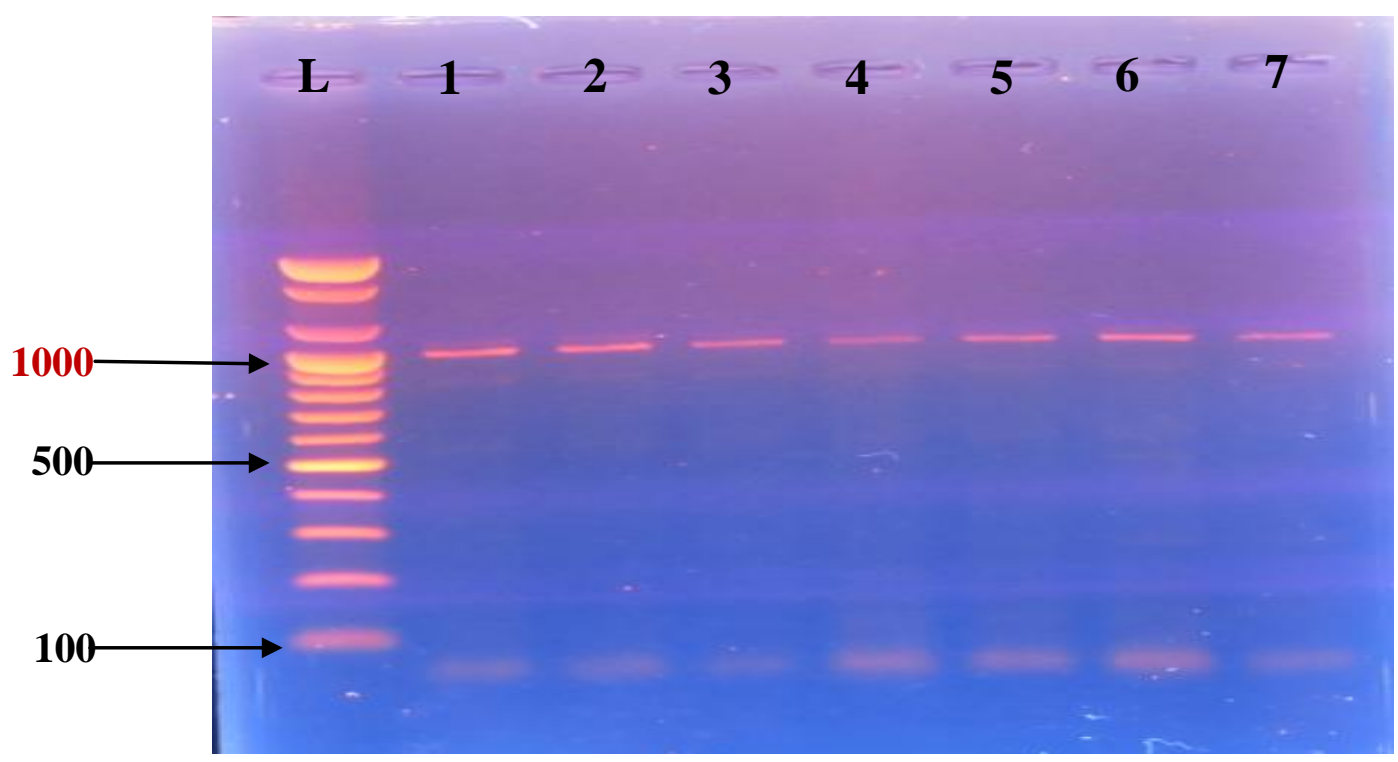

Fig.3 A/ Agarose gel electrophoresis of restriction enzyme Alu1 on ITS1 gene. L: Ladder (1500bp). (1) sheep liver, (2) and (3) liver and kidney of human, (4) cattle liver, (5) buffaloes liver and (6) Camel liver.

B/ Agarose gel electrophoresis of restriction enzyme Alu1 on ITS1 gene. L: Ladder (1500bp). (1) and (2) sheep lung, (3) and (4) human lung, (5) cattle lung, (6) buffaloes lung and (7) Camel lung.

A

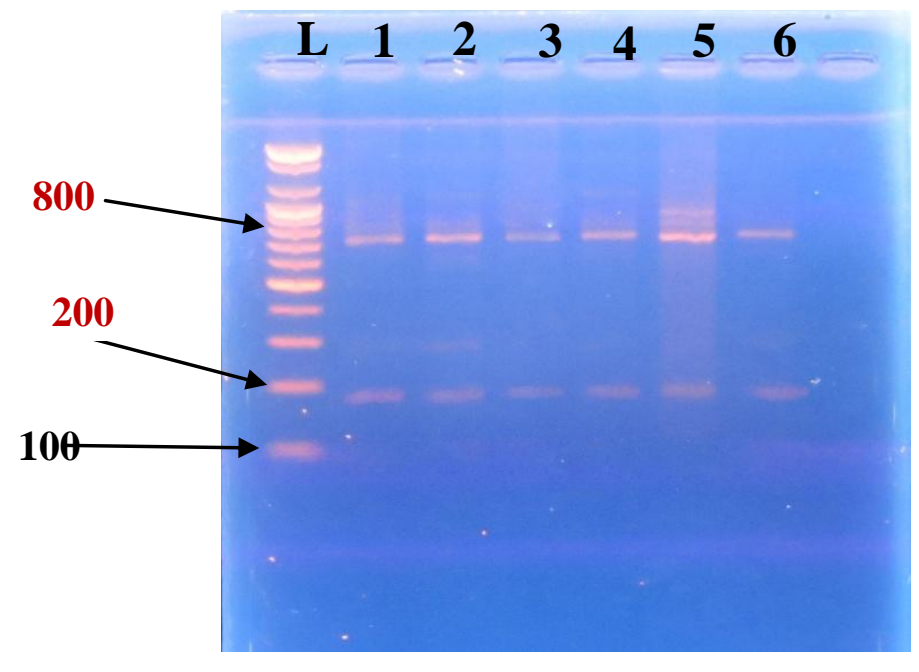

B

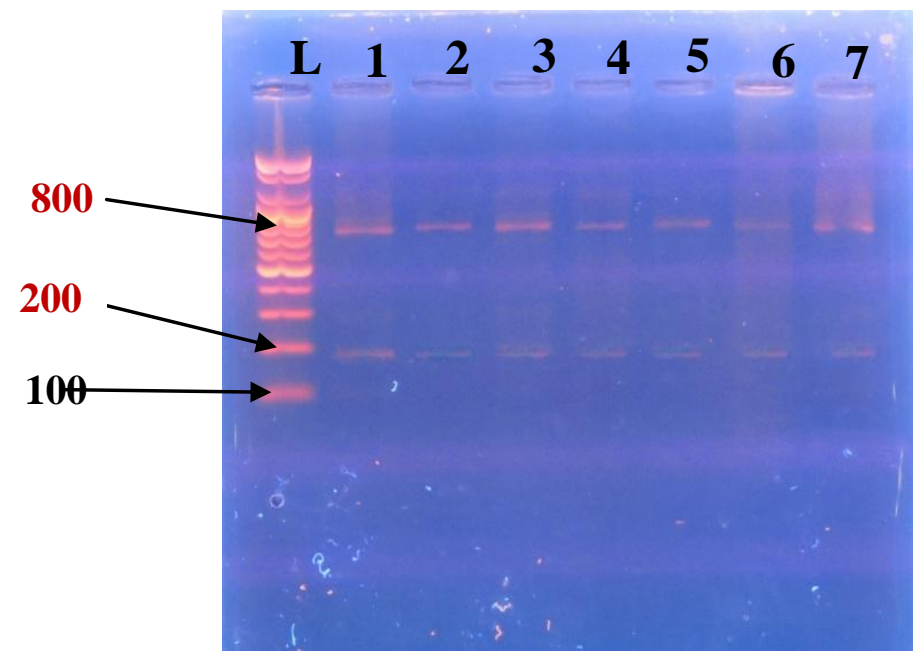


Fig.4 A/ Agarose gel electrophoresis of restriction enzyme Rsa1 on ITS1 gene. L: Ladder (1500bp). (1) and (2) sheep liver, (3) and (4) liver and kidney of human, (5) cattle liver, (6) buffaloes liver and (7) Camel liver.

B/ Agarose gel electrophoresis of restriction enzyme Rsa1 on ITS1 gene. L: Ladder (1500bp). (1) and (2) sheep lung, (3) and (4) human lung, (5) cattle lung, (6) buffaloes lung and (7) Camel lung.

A

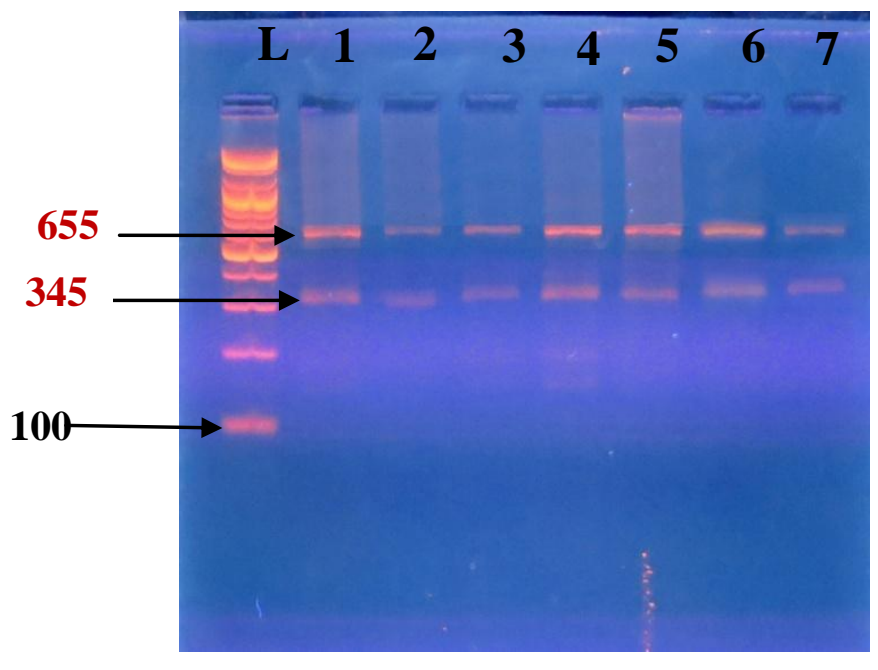

B

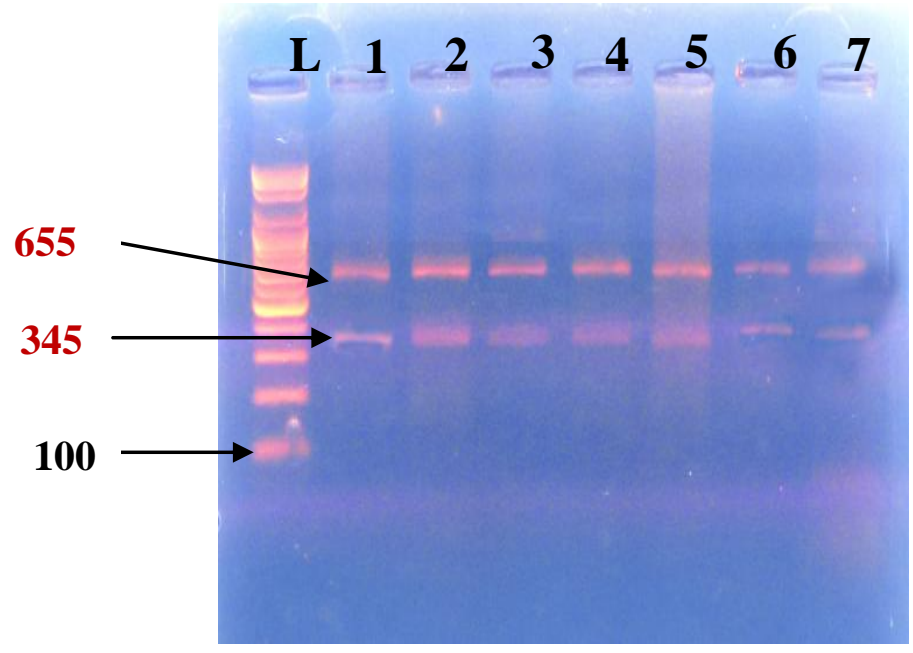

Fig.5 Nucleotide analysis of rDNA - ITS1 for sample of hydatid cyst isolated from sheep's liver.

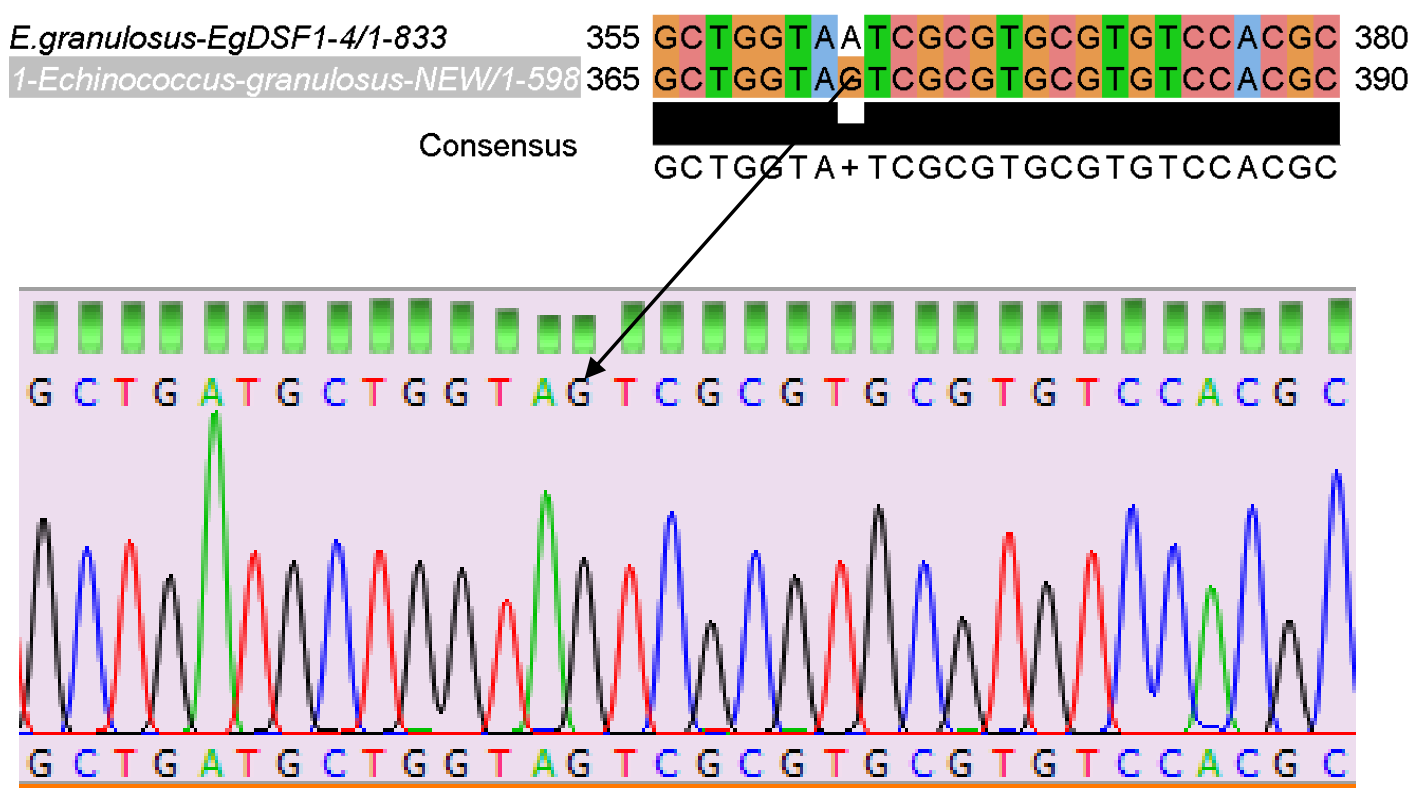

This study assessed the existence of sheep strain G1 in intermediate hosts and human and in different infected organs such as liver, lungs and kidney in human. Genotype of infecting strain is affected by the fertility rate of the cysts in the intermediate hosts 
and localization of the cysts (Thompson \& Lymbery, 1988).

Sequence analysis of ITS1 gene showed dominant sheep strain of E.granulosus in ours 10 samples after their comparison in gene bank except one sample isolated from sheep liver demonstrate genetic point mutation transition type causes in substitution nitrogenous base guanine instead adenine in position 370. Analysis of nucleotide sequence for this sample and their comparison with genotypes (G1 - G10) of E.granulosus showed dissimilarity with data bases for sequences of other genotypes in gene bank. Data base of this sample is recorded for the first time in gene bank in National Center of Biotechnology Information (NCBI) and European Nucleotide Archive (ENA) which represents a new strain of E.granulosus strain WH1AW2 (GenBank: LT547814.1) This genetic variation which represented by point transition mutation showed distinct strain that is similar to genotype G1 and $99 \%$ in sequence analysis. The present study shows the existence of genetic variability within Echinococcus genus which may be cause variation in biological type of parasite. These mutations produce a new genotypes of E.granulosus and may be lead to adaptation to local environmental circumstances and subsequently, contribute in maintenance and persistence the life of this new genotype. The wide intraspecific variation in E.granulosus may be linked to life cycle patterns, developmental rate, host specificity transmission methods and pathology. These variabilities lead to the identification of subspecific variants or strain that's why some authors have proposed a revision of the taxonomy of the genus Echinococcus (Thompson \& McManus, 2002).

The appearance of genetically different new strains within Echinococcus genus may be caused by crossing fertilization between different strains for Echinococcus genus. Haag et al., (1999) gave evidence to crossing fertilization between sheep and cattle strains of E.granulosus in southern of Brazil. The cause may be belong to hybridization which may be found between some strains of Echinococcus genus in final host. Rollinson et al., (1990) refer to mixing of rDNA and hybridization for different types from schistosomes. The occurrence of genetic variation may be explained by exposure to environmental factors (chemical and radiant materials) which causes genetic mutations and subsequently lead to appearance strain of different genetic structure.

\section{References}

Adwan, G.M., Adwan, K.M., Bdir, S. \& Abuseir, S. 2013). Molecular characterization of Echinococcus granulosus isolated from sheep in Palestine. Exp. Parasitol., 134: 195 199.

Ahmadi, N., Dalimi, A. 2006. Characterization of Echinococcus granulosus isolates from human, sheep and camel in Iran. Infect. Genet. Evol., 6(2): 85-90.

Aljawady, M.A. 2009. Sheep can be infected with more than one strain of Echinococcus granulosus. J. Ani. Vet. Adv., 8(11): $2177-2180$.

Al-Krawy, A.K.H. 2004. Comparative study for differentiation of some (Echinococcus granulosus) strains of different intermediate hosts (sheep, cow and goats) in Sallahuddin governorate. Thesis of Master, College of Education/ University of Tikrit.

Bhattacharya, D., Bera, A. K., Bera, B. C., Pan, D., \& Das, S. K. (2008). Molecular appraisal of Indian animal isolates of Echinococcus granulosus. Indian. J. Med. Res., 127: 383-287. 
Bhattacharya, D., Bera, A.K., Bera, B.C., Maity, A. \& Das, S.K. 2007. Genotypic characterisation of Indian cattle, buffalo and sheep isolates of Echinococcus granulosus. Vet. Parasitol., 143: 371-374.

Bouree, P. 2001. Hydatidosis : Dynamics of transmission. World J. Surg., 25: 4 9.

Bowles, J. \& McManus, D.P. 1993 b. Molecular variation in Echinococcus. Acta. Trop., 53: $291-305$.

Bowles. J. \& McManus, D.P. 1993a. Rapid discrimination of Echinococcus species and strains using a polymerase chain reaction-based RFLP method. Mol. Biochem. Parasitol., 57: 231239.

Eckert, J. \& Thompson, R.C.A. 1997. Intraspecific variation of Echinococcus granulosus and related species with emphasis on their infectivity to humans. Acta. Tropica., 64: $19-34$.

El- Madawy, R.S., Khalifa, N.O. \& Afify, J.S.A. 2011. Epidemiological and molecular studies of hydatid cyst in slaughtered cattle and sheep in Toukh, Egypt. Vet. Med. J., (I): 95 - 101 .

Haag, K.L., Araujo, A.M., Gottstein, B., Siles-Lucas, M., Thompson, R.C.A. \& Zaha, A. 1999. Breeding systems in Echinococcus granulosus (Cestoda: Taeniidae): selfing or outcrossing?. Parasitol., 118: 63 - 71.

Hanifian, H., Diba, K., Tappeh, K.H., Mohammadzadeh, H. \& Mahmoudlou, R. 2013. Identification of Echinococcus granulosus strains in isolated hydatid cyst specimens from animals by PCR-RFLP method in West Azerbaijan - Iran. Iranian J. Parasitol., 8(3): 376 - 381.

Harandi, M.F., Hobbs, R.P., Adams, P.J., Mobedi, I., Morgan-Ryan, U.M. \& Thompson, R.C. 2002. Molecular and morphological characterization of Echinococcus granulosus of human and animal origin in Iran. Parasitol., 125: 367-373.

Hobbs, R.P., Lymbery, A.J. \& Thompson, R.C.A. 1990. Rostellar hook morphology of Echinococcus granulosus (Batsch, 1786) from natural and experimental Australian hosts, and its implications for strain recognition. Parasitol., 10: 273 - 281.

Huttner, M., Nakao, M., Wassermann, T., Siefert, L., Boomker, J.D.F., Dinkel, A., Sako, Y., Mackenstedt, U., Romig, T. \& Ito, A. 2008. Genetic characterization and phylogenetic position of Echinococcus felidis ortleppi, 1937 (Cestoda : Taeniidae) from the African Lion. Int. J. Parasitol., 38: 861 - 868.

Jamali, R., Ghazanchaei, A. \& Asgharzadeh, M. 2004. Identification and characterization of Echinococcus granulosus by PCR-RFLP technique in Tabriz district. J. Parasitic Dis., 28(2): 69-72.

Karimi, A. \& Dianatpour, R. 2008. Genotypic and phenotypic Characterization of Echinococcus granulosus of Iran. Biotech., 7(4): 757-762.

Khalf, M.S., Al-Faham, M.A., Al-Taie, L. H. \& Alhussian, H.A. 2014. Genotyping of Echinococcus granulosus in samples of Iraqi patients. IOSR J. Pharm. Bio. Sci., (IOSR-JPBS). 9(3): $6-10$.

Khalifa, N.O., Khater, H.F., Fahmy, H.A., Radwan, M.E.I. \& Afify, J.S.A. 2014. Genotyping and Phylogenetic Analysis of Cystic Echinococcosis Isolated from Camels and Humans in Egypt. Amer. J. Epid. Infect. Dis., 2(3): 7482.

McManus, D.P. \& Smyth, J.D. 1986. Changing concepts in epidemiology 
and speciation. Parasit. Today, 2: 163 $-168$.

McManus, D.P. \& Thompson, R.C.A. 2003. Molecular epidemiology of cystic echinococcosis. Parasitol., 127: 37 51.

Molan, A.L. 1993. Epidemiology of Hydatidosis and Echinococcosis in Theqar province, southern Iraq. Japan. J. Med. Sci. Biol., $46: 29-35$.

Nakao, M., McManus, D. P., Schantz, P.M., Craig, P.S. \& Ito, A. 2007. A molecular phylogeny of the genus Echinococcus inferred from complete mitochondrial genomes. Parasitol., 134: $713-722$.

Parija, S.C. 2004. Hydatid fluid as clinical specimen for the aetiological diagnosis of a suspected hydatid cyst. $J$. Parasitol., 28: $64-68$.

Parsa, F., Haghpanah, B., Pestechian, N. \& Salehi, M. 2011. Molecular epidemiology of Echinococcus granulosus strains in domestic herbivores of Lorestan, Iran. Jun. J. Microbio., (JJM). 4(2): 123 - 130.

Rinaldi, M., Maurelli, P., Capuano, F., Perugin, A.G., Veneziano, V. \& Cringoli, S. 2008. Molecular update on cystic echinococcosis in cattle and water buffaloes of southern Italy. Zoon. Pub. Heal., 55: $119-123$.

Rollinson, D., Walker, T. K., Knowles, R. J. \& Simpson, A.J.G. 1990. Identification of schistosome hybrids and larval parasites using rRNA probes. Systematic Parasitol., 15:6573.

Romig, T., Dinkel, A. \& Mackenstedt, U. 2006. The present situation of echinococcosis in Europe. Parasitol. Int., 55: 187-91.

Sambrook, J., Fritsh, E.F. \& Maniatis, T. 1989. Molecular cloning. A laboratory manual, $2^{\text {nd }}$ Ed. Cold spring Harbor Laboratory Press. USA.
Sanchez, E., Caceres, O., Naquira, C., Garcia, D. \& Patino, G. 2010. Molecular characterization of Echinococcus granulosus from Peru by sequencing of the mitochondrial Cytochrome c oxidase subunit 1 gene, Oswaldo Cruz, Rio de Janeiro, 105(6).

Shahzad, W., Abbas, A., Munir, R., Khan, M. S., Avais, M., Ahmad, J., Rana, M. Y. \& Mehmood, F. 2014. A PCR analysis of prevalence of Echinococcus granulosus genotype G1 in small and large ruminants in three districts of Punjab, Pakistan. Pakistan J. Zool., 46(6):1541-1544.

Snabel, V., Altınta, N., D'Amelio, S., Nakao, M., Romig, T., Yolası_maz, A., Güne, K., Türk, M., Busi, M., Hüttner, M., Sevcova, D., Ito, A. \& Dubinsky, P. 2009. Cystic echinococcosis in Turkey: genetic variability and first record of the pig strain (G7) in the country. Parasitol. Res., 105: 145 - 154.

Thompson, R.C.A. \& Lymbery, A.J. 1988. The nature, extent and significance of variation the genus Echinococcus. Adv. Parasitol., 27: 209-258.

Thompson, R.C.A. \& Lymbery, A.J. 1995. Echinococcus and hydatid disease. UK, CAB International Press., 89 103.

Thompson, R.C.A., Boxelli, b.J., Raslston, C.C., Constantine, C.C., Hobbs, R.P., Shury, T. \& Olson, M.E. 2006. Molecular and morphological characterization of Echinococcus in Cervids from North America. Parasitol., 132: 439-447.

Thompson, R.C. \& Mc Manus, D.P. 2002. Towards a taxonomic revision of the genus Echinococcus. Trends, Parasitol., 18: 452 - 457.

Utuk, A.E., Simsek, S., Koroglu, E. \& Mc Manus, D.P. 2008. Molecular genetic characterization of different isolates of 
Echinococcus granulosus in east and southeast regions of Turkey. Acta. Trop., 107: 192-194.

Vahedi, A., Mahdavi, M., Ghazanchaei, A. \& Shokouhi, B. 2014. Genotypic characteristics of hydatid cysts isolated from humans in East Azerbaijan province (2011 - 2013). J. Anal Res. Clin. Med., 2(3): 152 - 157.

Van Herwerden, L., Gasser, R. B. \& Blair, D. 2000. ITS-1 ribosomal DNA sequence variants are maintained in different species and strains of
Echinococcus. Int. J. Parasitol., 30: $157-169$.

Vural, G., Unsal Baca, A., Gauci, C.G., Bagci, O., Gicik, Y. \& Lightowlers, M.W. 2008. Variability in the Echinococcus granulosus cytochrome C oxidase 1 mitochondrial gene sequnce from livestok in Turkey and a re-appraisal of the G1-3 genotype cluster. Vet. Parasitol., 154: 347- 350.

WHO. 2002. Manual on Echinococcosis in Humans and Animals: a Public Health Problem of Global Concern, 11-3.

\section{How to cite this article:}

Wesam Jasim Hansh and Abdul-Hussien Habash Awad. 2016. Genotyping Study of Hydatid Cyst by Sequences of ITS1 - rDNA in Thi-Qar - Southern of Iraq. Int.J.Curr.Microbiol.App.Sci. 5(8): 350-361. doi: http://dx.doi.org/10.20546/ijcmas.2016.508.037 